Proc. Indian Acad. Sci., Vol. 88 A, Part II, Number 1, March 1979, pp. 29-40. e printed in India.

\title{
Annual fallout of ${ }^{32} \mathrm{Si},{ }^{210} \mathrm{~Pb},{ }^{22} \mathrm{Na},{ }^{35} \mathrm{~S}$ and ${ }^{7} \mathrm{Be}$ in rains in India
}

\author{
D LAL, V N NIJAMPURKAR, G RAJAGOPALAN* and \\ B L K SOMAYAJULU \\ Physical Research Laboratory, Ahmedabad 380009 \\ * Birbal Sahni Institute of Palaeobotany, Lucknow 226007
}

MS received 4 December 1978; revised 6 February 1979

\begin{abstract}
The concentration of radioisotopes ${ }^{7} \mathrm{Be}$, ${ }^{25} \mathrm{~S}$ were measured in Bombay since 1956 and ${ }^{22} \mathrm{Na},{ }^{210} \mathrm{~Pb},{ }^{32} \mathrm{Si}$ since 1963 . In Khandala and other stations such measurements have been made at irregular periods since 1961. In addition several measurements especially that of ${ }^{32} \mathrm{Si}$ were made in 1970 . Data available todate from Indian stations is summarised and critically analysed.

We conclude that appreciable amounts of ${ }^{35} \mathrm{~S},{ }^{28} \mathrm{Na}$ and ${ }^{32} \mathrm{Si}$, over and above their production by cosmic rays, were produced during the high yield Russian tests as evidenced by their fallout between 1962-66. Based on the bomb produced excess the half period for their removal from the stratosphere is deduced to be less than 1 year. The ' excess' contribution of ${ }^{32} \mathrm{Si}$ due to bombs is, however, small; about $1 \%$ of its inventory in the oceans.

The present study shows that for stations where orogeny is the principal mechanism of precipitation, the annual fallout is independent of the annual rainfall.
\end{abstract}

Keywords. Cosmic rays; radioisotopes; rainwater; fallout.

\section{Introduction}

The usefulness of cosmic ray produced radioisotopes towards understanding the atmospheric circulation has long been demonstrated (see Lal and Peters 1967 for a review). ${ }^{210} \mathrm{~Pb}$ (the daughter of ${ }^{22} \mathrm{Rn}$ which emanates from the earth) and its daughter products have also been shown to be useful for studying short-term atmospheric wash out of processes (Bhandari and Rama 1963; Bhandari 1965; Joshi et al 1969; Rangarajan et al 1975; Turekian et al 1977). It is known that some of the radioisotopes ${ }^{7} \mathrm{Be},{ }^{35} \mathrm{~S}$ and ${ }^{22} \mathrm{Na}$ have also been produced in large amounts due to testing of nuclear weapons and that this ' excess' production has significantly altered the natural levels of these isotopes, both in the atmosphere and in the hydrosphere. Dansgaard et al (1966) reported evidence for production of ${ }^{32} \mathrm{Si}$ in 1963,1964 rains ; this isotope of half-life 300 years (Jantsch 1967; Lal et al 1970a; Clausen 1973) is useful in groundwater and glaciological studies. Production of radionuclides in atmospheric tests upsets the natural balance only for a short period in the case of shortlived isotopes; however, in the case of longlived isotopes like ${ }^{32} \mathrm{Si}$ and ${ }^{14} \mathrm{C}$, the natural inventories remain disturbed over long periods. Measurements of the concentration of isotopes in rains form a convenient way to ascertain the 
contributions, if any, from nuclear explosions. Such measurements are essential for the use of these isotopes as tracers for studying atmospheric circulation (Bhandari et al 1970), hydrology (Lal et al 1970b) and oceanic mixing (Lal and Suess 1968).

Some of the cosmogenic radio isotopes mentioned above have been measured in rains at Bombay and at other stations in India during 1955-71. We have measured ${ }^{32} \mathrm{Si}$ fallout in rains during 1961-71. Extensive measurements were made of ${ }^{32} \mathrm{Si},{ }^{22} \mathrm{Na},{ }^{7} \mathrm{Be},{ }^{210} \mathrm{~Pb}$ and ${ }^{35} \mathrm{~S}$ in 1970 at two stations, Bombay and Khandala to study the variations for different rainfall collections during one season. The year 1970 was chosen for these studies to establish cosmic ray produced level for these isotopes for the following reason. Subsequent to the USA-USSR tests in late 1962, there was a moratorium on the testing of weapons and considering the mean removal time of approximately 1 year observed for these tests, one would expect a reduction by two orders of magnitude in the 'excess' activities produced. We present these data here and along with a summary of the fallout data during 1955-71 for the isotopes ${ }^{7} \mathrm{Be},{ }^{35} \mathrm{~S},{ }^{22} \mathrm{Na}$ and ${ }^{32} \mathrm{Si}$. The contributions of 'excess' activities of ${ }^{32} \mathrm{Si}$ produced due to nuclear weapon testing are also estimated.

\section{Experimental techniques}

In 1970, three continuous collections at Bombay and six at Khandala were made covering the entire monsoon period. About 5-15 tons of rainwater was collected from each station in plastic swimming-pool type tanks (Nijampurkar 1974). A separate rain gauge was kept at each station along with the tank. When the tank was nearly full (no overflowing was allowed), the water was stirred well, and about 200-400 litres was taken for ${ }^{22} \mathrm{Na} ;{ }^{35} \mathrm{~S},{ }^{7} \mathrm{Be}$, and ${ }^{210} \mathrm{~Pb}$ analyses. Reference to the methods used for radiochemistry and radioassay are given in table 1. After each

Table 1. Relevant details and methods of analysis of the radioisotopes investigated.

\begin{tabular}{|c|c|c|c|c|}
\hline Isotope & Half-life & $\begin{array}{l}\text { Energy of the } \\
\text { principal radiation } \\
\text { emitted (MeV) }\end{array}$ & Method of assay & Reference \\
\hline${ }^{7} \mathrm{Be}$ & $53.6 d$ & $E_{\gamma}=0.477$ & $\begin{array}{l}\text { Radiochemistry and } \\
\gamma \text {-counting }\end{array}$ & $\begin{array}{c}\text { Goel et al 1956; } \\
\text { Bhandari } 1965\end{array}$ \\
\hline${ }^{35} \mathbf{S}$ & $87.9 d$ & $E_{\max } \beta^{-}=0.167$ & $\begin{array}{l}\text { Radiochemistry and } \\
\beta \text {-counting }\end{array}$ & $\begin{array}{l}\text { Goel } 1956 ; \\
\text { Somayajulu and } \\
\text { Zutshi } 1961\end{array}$ \\
\hline${ }^{22} \mathrm{Na}$ & $2 \cdot 62 y$ & $E_{\max } \beta^{+}=1.82$ & $\begin{array}{l}\text { Radiochemistry and } \\
\gamma-\gamma \text { coincidence } \\
\text { counting }\end{array}$ & $\begin{array}{l}\text { Bhandari and Rama } \\
1963\end{array}$ \\
\hline${ }^{210} \mathrm{~Pb}$ & $22 \cdot 2 y$ & $E_{\max } \beta^{-}=0.061$ & $\begin{array}{l}\text { Radiochemistry and } \\
\text { beta assay of } \\
\text { daughter }{ }^{210} \mathrm{Bi} \\
\left({ }_{t}=5 d ;\right. \\
\left.E_{\mathrm{mgx}} \beta^{-}=1.16 \mathrm{MeV}\right)\end{array}$ & Bhandari 1965 \\
\hline $25 \mathrm{Si}$ & $300 y$ & $E_{\mathrm{mEx}} \beta^{-}=0.21$ & $\begin{array}{l}\text { Radiochemistry and } \\
\text { beta assay of } \\
\text { daughter } 32 \mathrm{P} \\
\left(t_{t}=14.3 \mathrm{~d} ;\right. \\
\left.E_{\max } \beta^{-}=1.7 \mathrm{MeV}\right)\end{array}$ & $\begin{array}{c}\text { Kharkar et al } \\
1963,1966\end{array}$ \\
\hline
\end{tabular}


collection, the tank was cleansed with $25 \% \mathrm{HCl}$ solution, washed with distilled water and then kept for the next collection along with a rain gauge.

\section{Results and discussion}

The data on fallout of ${ }^{7} \mathrm{Be},{ }^{35} \mathrm{~S},{ }^{22} \mathrm{Na},{ }^{210} \mathrm{~Pb}$ and ${ }^{32} \mathrm{Si}$ during 1970 are presented in table 2.

The ${ }^{32} \mathrm{Si}$ concentrations at Khandala during different periods are seen to be remarkably constant, except for the last period of collection. At Bombay and Khandala, ${ }^{32} \mathrm{Si}$ concentrations are about the same within the errors of measurement; this is also to be expected considering the nearness of the two stations $(\sim 130 \mathrm{~km})$. The relative concentrations ${ }^{22} \mathrm{Na},{ }^{35} \mathrm{~S}$ and ${ }^{7} \mathrm{Be}$ are significantly different for the different collections at Khandala. The samples analysed are too few at Bombay to infer any change in the fallout for these isotopes except for ${ }^{22} \mathrm{Na}$ where the two Bombay samples differ by more than a factor of two. The concentrations of ${ }^{210} \mathrm{~Pb}$ in the Khandala samples range from 3.2 to $5.5 \mathrm{dpm}$ per litre; the variation is similar to that found by Bhandari (1965).

The mean ${ }^{32} \mathrm{Si}$ concentration at Ludhiana $\left(30^{\circ} 56^{\prime} \mathrm{N}\right)$ is $0.38 \mathrm{dpm} / 10^{3}$ litres; this is high compared to the mean values observed at Bombay and Khandala (19$\left.20^{\circ} \mathrm{N}\right)$, viz., $(0 \cdot 17-0 \cdot 22) \mathrm{dpm} / 10^{3}$ litres. The fallout studies at Pathankot $\left(32^{\circ}\right.$ $14^{\prime} \mathrm{N}$ ) made in 1961 (Kharkar et al 1963) and in 1963 (Bhandari, 1965) yielded similar high concentration values which are expected due to the higher latitude of these stations where significant contributions arise due to downward mixing of stratospheric air.

For Bombay, the deduced mean-annual fallout values $\left(\mathrm{dpm} / \mathrm{cm}^{2}\right)$ for ${ }^{7} \mathrm{Be},{ }^{35} \mathrm{~S}$, ${ }^{22} \mathrm{Na},{ }^{210} \mathrm{~Pb}$ and ${ }^{32} \mathrm{Si}$ from 1955 till 1971 are given in table 3. All the isotopes were not measured during these years as can be seen from table 3 ; the existing data are pooled in table 3. The fallout of the cosmogenic isotopes as a function of the year of collection is shown in figure 1. [The annual fallout, $\mathrm{dpm} / \mathrm{cm}^{2}$, is calculated by multiplying the mean annual concentration (dpm/litre) and the annual rainfall (litres $/ \mathrm{cm}^{2}$ ).] The annual fallout of ${ }^{90} \mathrm{Sr}$ during this period is also given in figure 1. The following features become evident from the data given in table 3 and figure 1.

(i) There are two years of " high" fallout of ${ }^{35} \mathrm{~S}$. The high values were observed in $1956,4 \cdot 5 \mathrm{dpm} / \mathrm{cm}^{2}$ when it was first detected (Goel 1956) and in 1958 $\left(2.8 \mathrm{dpm} / \mathrm{cm}^{2}\right)$. By 1961 it came down to $0.26 \mathrm{dpm} / \mathrm{cm}^{2}$. There had been several nuclear detonations between 1956-58 which can account for the high ${ }^{35}$ S fallout. Later, the high-yield USA and USSR tests in late 1962 have significantly contributed to both ${ }^{35} \mathrm{~S}$ and ${ }^{22} \mathrm{Na}$ (Bhandari 1965). The observed peak in 1963 though small is a result of this. The fallout of ${ }^{85} \mathrm{~S}$ in 1964 is $0.17 \mathrm{dpm} / \mathrm{cm}^{2}$ which is about the same as the 1970 fallout value. The 1970 value is indicated to be close to the natural fallout-level of ${ }^{35} \mathrm{~S}$ produced by cosmic rays.

(ii) There exist large fluctuations in the 'Be deposition rate and some of these could be attributed to nuclear weapons' testing; the total range of variations is however small to reach any definite conclusions. The mean value for the period $1955-70$ is deduced to be $7 \cdot 6 \pm 2 \cdot 5 \mathrm{dpm} / \mathrm{cm}^{2}$. 


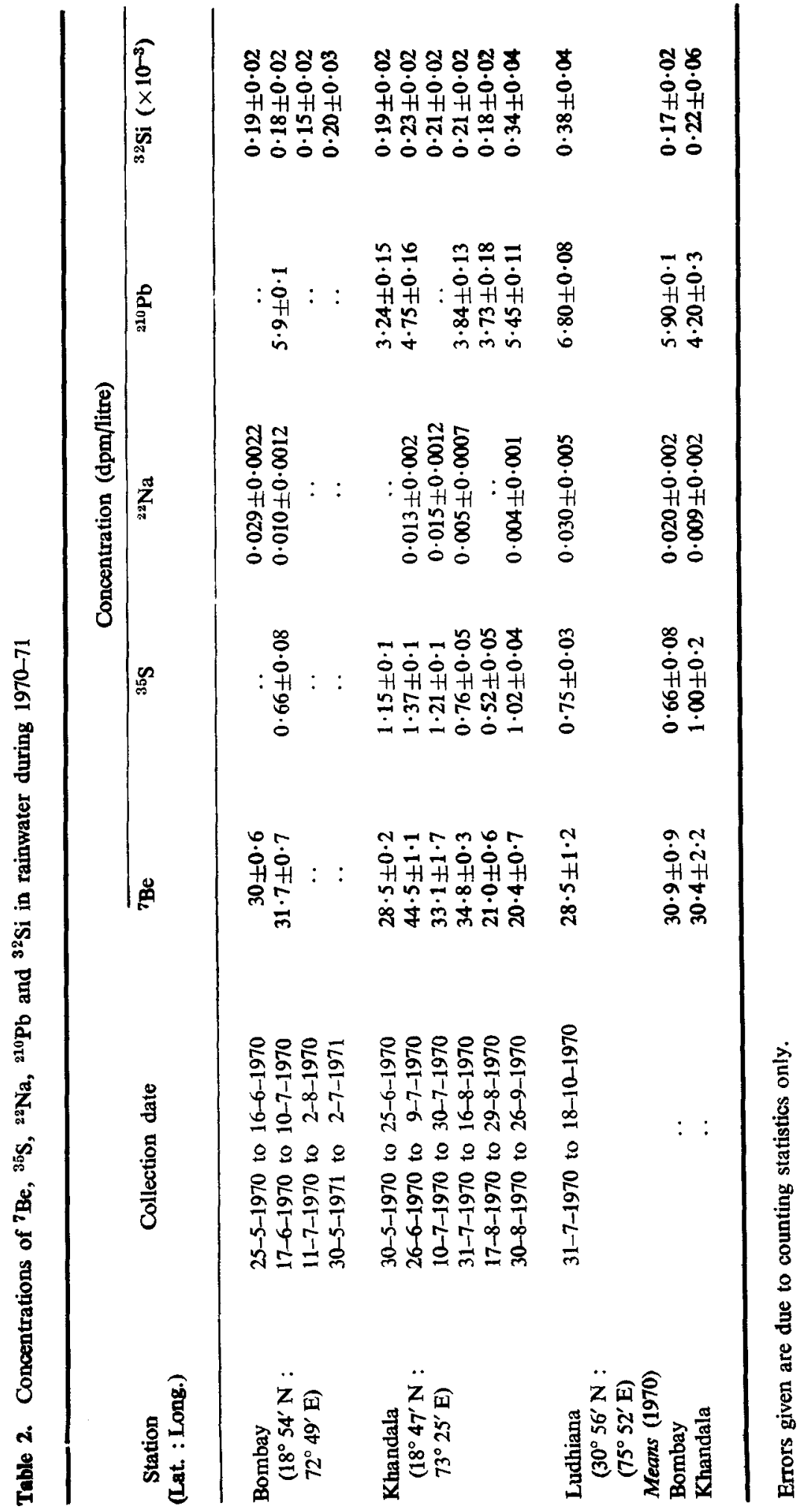


Table 3. Annual fallout of ${ }^{7} \mathrm{Be},{ }^{35} \mathrm{~S},{ }^{22} \mathrm{Na},{ }^{810} \mathrm{~Pb}$ and ${ }^{32} \mathrm{Si}$ in Bombay rains.

\begin{tabular}{|c|c|c|c|c|c|c|}
\hline \multirow{2}{*}{ Year } & \multirow{2}{*}{$\begin{array}{l}\text { Rainfall } \\
\text { (mm) }\end{array}$} & \multicolumn{5}{|c|}{ Annual fallout $\left(\mathrm{dpm} / \mathrm{cm}^{2}\right)$} \\
\hline & & $\mathrm{iBe}_{\mathrm{Be}}$ & ${ }^{35} \mathrm{~S}$ & ${ }^{2} \mathrm{Na} \times 10^{3}$ & ${ }^{210} \mathrm{~Pb}$ & $32 \mathrm{Si} \times 10^{5}$ \\
\hline 1955 & 2252 & 4.9 & & . & . & $\cdots$ \\
\hline 1956 & 2573 & $9 \cdot 3$ & $4 \cdot 5$ & .. & .. & 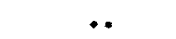 \\
\hline 1957 & 1773 & $5 \cdot 5$ & 0.5 & . & $\cdots$ & $\cdots$ \\
\hline 1958 & 3319 & $13 \cdot 2$ & $2 \cdot 8$ & . & . & .. \\
\hline 1959 & 2394 & $6 \cdot 3$ & 0.51 & .. & . & .. \\
\hline 1961 & 2206 & $5 \cdot 7$ & $0 \cdot 26$ & . & . & $2 \cdot 2 \pm 0 \cdot 4$ \\
\hline 1962 & 2030 & . & $\cdots$ & . & $\ldots(2 \cdot 0)$ & $8 \cdot 1 * *$ \\
\hline 1963 & 2531 & $9 \cdot 6$ & 0.44 & $18 \cdot 0$ & $1 \cdot 1 \quad(1 \cdot 1)$ & $12 \cdot 0 \pm 2 \cdot 0$ \\
\hline 1964 & 1964 & $6 \cdot 8$ & $0 \cdot 17$ & .. & $1 \cdot 2 *(1 \cdot 4)$ & $17 \cdot 0 \pm 2 \cdot 0$ \\
\hline 1965 & 2024 & $8 \cdot 3$ & . & $4 \cdot 0$ & $\ldots(2 \cdot 0)$ & \\
\hline 1966 & 1561 & . & .. & . & $1 \cdot 9 *(1 \cdot 3)$ & $4 \cdot 8 \pm 0 \cdot 7$ \\
\hline 1967 & 2373 & . & .. & .. & $1 \cdot 3^{*}$ & $4 \cdot 3 \pm 0 \cdot 3$ \\
\hline 1968 & 1381 & $5 \cdot 6$ & 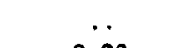 & $2 \cdot 0$ & . & $5 \cdot 0 \pm 0 \cdot 6$ \\
\hline 1970 & 2626 & $8 \cdot 1$ & 0.23 & $4 \cdot 0$ & $1 \cdot 6$ & $4 \cdot 6 \pm 0.5$ \\
\hline 1971 & 2444 & .. & . & .. & . & $4 \cdot 9 \pm 0 \cdot 5$ \\
\hline \multicolumn{2}{|c|}{ Theoretical*** } & $4 \cdot 1(12 \cdot 3)$ & $0.06(0.17)$ & $2 \cdot 1$ & .. & $3 \cdot 3$ \\
\hline
\end{tabular}

Errors due to counting statistics for $\mathrm{Be}-7, \mathrm{~S}-35$ and $\mathrm{Pb}-210$ are $10 \%$, for $\mathrm{Na}-22,20 \%$ and for $\mathrm{Si}-32$ are indicated in the table.

* Data from Joshi et al (1969). Numbers in parentheses are surface deposition values for $\mathrm{Pb}-210$ in units of $\mathrm{dpm} / \mathrm{cm}^{2}$ as measured in air filters (Gopalakrishnan et al 1973).

** Ascertained from Table 5, see discussion ahead.

*** Theoretical fallout values are calculated using table 3 and figure 22 of Lal and Peters (1967). Total atmospheric production rate is used in the case of $\mathrm{Si}-32, \mathrm{Na}-22$ and tropospheric production rate for $\mathrm{S}-35$ and $\mathrm{Be}-7$. Numbers in parentheses indicate fallout calculated using the total production rate.

(iii) ${ }^{22} \mathrm{Na}$ measurements were made only since 1963 . The 1963 value is quite high, $0.018 \mathrm{dpm} / \mathrm{cm}^{2}$ a result of the weapons' tests in 1961-62. After one year (in 1964), the ${ }^{22} \mathrm{Na}$ fallout dropped down to $0.006 \mathrm{dpm} / \mathrm{cm}^{2}$. The three measurements in 1965, 1968 and 1970 are all about the same, viz., $0.004 \mathrm{dpm} / \mathrm{cm}^{2}$. These values should therefore represent the natural cosmogenic levels.

(iv) The ${ }^{32} \mathrm{Si}$ fallout was considerably high during 1963 and 1964 . No ${ }^{32} \mathrm{Si}$ fallout measurements were made in Bombay in 1961; however, at Khandala one measurement exists which is included in figure 1 in order to make a comparison between the pre-bomb and post-bomb fallout of ${ }^{32} \mathrm{Si}$. The ${ }^{32} \mathrm{Si}$ fallout values after the 1964 peak (1966-71) are higher than the 1961 value at least by a factor of two. The low value could also be due to the fact that a cement tank was used in 1961. (The cement tank which was used only during 1961 could have absorbed some silicon-32 from the rainwater). In later years, swimming pool-type PVC tanks were used; the pvc tanks were acid-washed before each collection. 


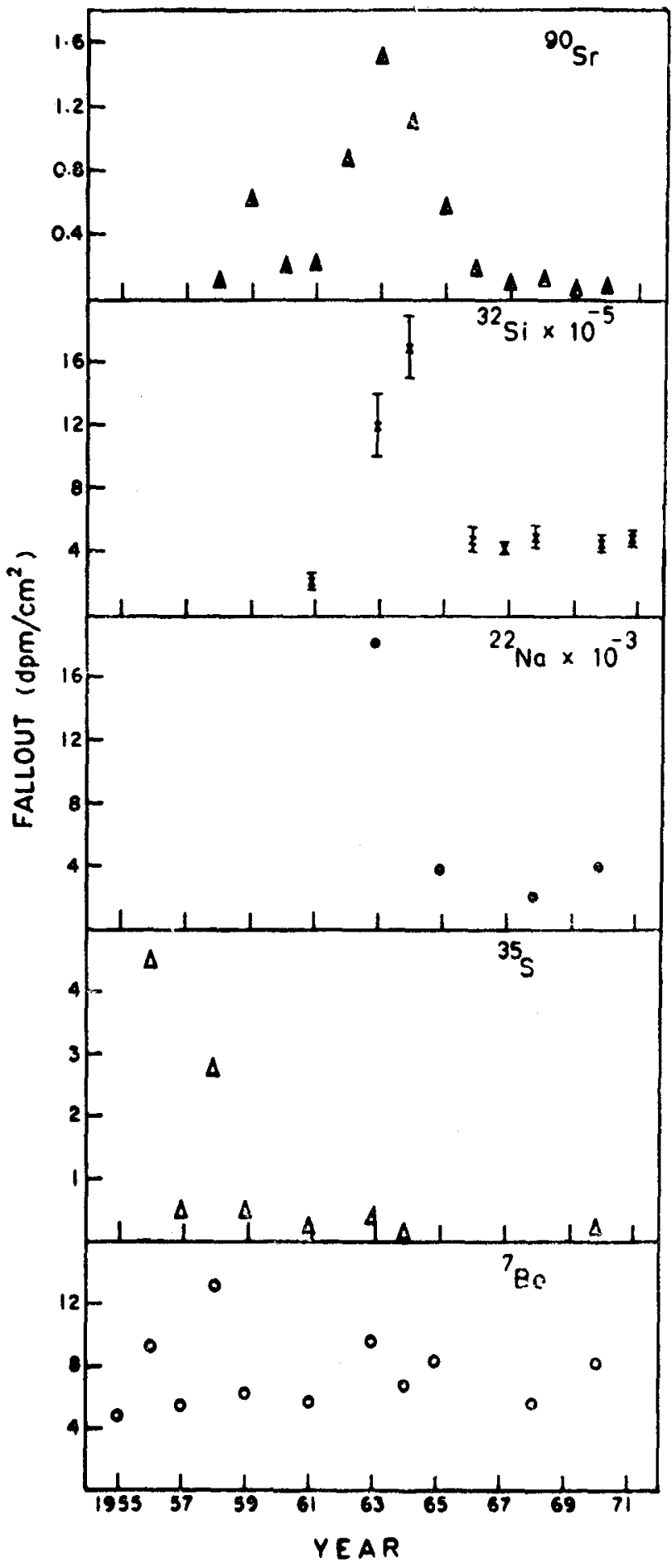

Figure 1. Annual fallout of cosmogenic radioisotopes as a function of year. The annual fallout of man-made ${ }^{\circ 0} \mathrm{Sr}$ for the Bombay-Khandala latitudes is also shown for comparison. 
It is clear that there are two peaks in the ${ }^{\circ} \mathrm{Sr}$ fallout pattern during 1959 and 1963 (figure 1), both indicating nuclear explosions during these (or in the preceding) years. From the data given in table 3 (also figure 1), it can be deduced that the half period for removal of ' excess' (bomb-produced) components of ${ }^{22} \mathrm{Na}$ and ${ }^{32} \mathrm{Si}$ is less than 1 year.

The annual ${ }^{210} \mathrm{~Pb}$ wet fallout ranges from 1.1 to $1.9 \mathrm{dpm} / \mathrm{cm}^{2}$ during the years 1963 to 1970 which is about the same as its surface deposition values based on analyses of air filters (Gopalakrishnan et al 1973). There is no similarity between the fallout pattern of ${ }^{210} \mathrm{~Pb}$ and ${ }^{90} \mathrm{Sr}$ (table 3 ; figure 1) showing that the ${ }^{210} \mathrm{~Pb}$ production from nuclear weapons (Jawarowski and Kownacka 1976) may not be significant based on the measurements at Bombay and Khandala stations.

\section{Fallout pattern of ${ }^{32} \mathrm{Si}$}

Except for seasonal variations due to meteorological fluctuations, the fallout of a cosmogenic radionuclide at any given station would be expected to be constant provided it is entirely produced by cosmic rays. However, in the case of a longlived nuclide (half life greater than a few months) some seasonal variations may be expected due to an enhanced stratospheric-tropospheric mixing during spring. Dansgaard et al (1966) have shown that during the 1962 tests ${ }^{32} \mathrm{Si}$ was produced as evidenced by its high fallout during the succeeding years. The mean-annual fallout of ${ }^{32} \mathrm{Si}$ was high at most of the stations during 1963 and 1964 . We have summarised all the individual ${ }^{32} \mathrm{Si}$ fallout measurements made at all Indian stations in table 4. During some years we made three to six fallout collections in Bombay and Khandala, but during other years, at other stations, generally we made only one composite collection for the whole year.

In order to study the nature of variations during the period of collection, we have calculated the " normalised annual fallout" value for each collection period; this has been calculated by multiplying the average concentration value during the period of collection by the annual rainfall. These values are shown in figure 2 and in table 4. It is clearly seen that the " normalised annual value " at any given station is generally constant during a given year excepting during the two years $(1963,1964)$ following the 1962 tests, especially at Bombay and Khandala. Thus, we believe that the annual fallout values subsequent to and during 1966 represent the cosmogenic levels (also see table 3).

\subsection{Variations in ${ }^{32} \mathrm{Si}$ concentrations with rainfall}

An opportunity to study the dependency of fallout of cosmogenic radioisotope, ${ }^{32} \mathrm{Si}$ is provided by the data collected during the years 1961-71 at two stations, Bombay and Khandala where the annual rainfall varied by over a factor of two during the years of study. In our analysis, we exclude the data for the years 1963 and 1964 since during this period significant amounts of non-cosmogenic production occurred due to nuclear-weapon-testing.

First we note that for individual collections (table 4) the ${ }^{32} \mathrm{Si}$ concentration values do not show any correlation with the rainfall probably due to the large scatter expected as a result of normal meteorological fluctuations. However, the annualmean-concentrations of ${ }^{32} \mathrm{Si}$ are seen to vary inversely with the annual rainfall 
Table 4. ${ }^{32} \mathrm{Si}$ fallout in rains at different stations in India.

\begin{tabular}{|c|c|c|c|c|c|}
\hline $\begin{array}{l}\text { Station } \\
\text { (Latitude } \\
\text { Longitude) }\end{array}$ & $\begin{array}{l}\text { Date of c } \\
\text { From }\end{array}$ & $\begin{array}{l}\text { lection } \\
\text { To }\end{array}$ & $\begin{array}{l}\text { Rainfall* } \\
\text { during collec- } \\
\text { tion period } \\
\quad(\mathrm{cm})\end{array}$ & $\begin{array}{c}{ }^{32} \mathrm{Si} \text { con- } \\
\text { centration } \\
\left.\text { (dpm/10 } / 0^{3} \text { litres }\right)\end{array}$ & $\begin{array}{l}\text { Annual** } \\
\text { fallout } \\
\left(\mathrm{dpm} / \mathrm{cm}^{2}\right) \\
\times 10^{6}-\end{array}$ \\
\hline $\begin{array}{l}\text { Pathankot } \\
\left(32^{\circ} 14^{\prime} \mathrm{N},\right. \\
\left.75^{\circ} 38^{\prime} \mathrm{E}\right)\end{array}$ & $\begin{array}{r}26-8-1961 \\
29-6-1963 \\
1-2-1968\end{array}$ & $\begin{array}{r}5-3-1962 \\
28-9-1963 \\
12-12-1968\end{array}$ & $\begin{array}{l}60(125) \\
80(95) \\
71(71)\end{array}$ & $\begin{array}{l}0.27 \pm 0.07 \\
0.70 \pm 0.10 \\
0.47 \pm 0.08\end{array}$ & $\begin{array}{l}34 \pm 9 \\
67 \pm 10 \\
33 \pm 6\end{array}$ \\
\hline $\begin{array}{l}\text { Ludhiana } \\
\left(30^{\circ} 56^{\prime} \mathrm{N},\right. \\
\left.75^{\circ} 52^{\prime} \mathrm{E}\right)\end{array}$ & $31-7-1970$ & $18-10-1970$ & $44(70)$ & $0.38 \pm 0.04$ & $27 \pm 3$ \\
\hline $\begin{array}{l}\text { Gwalior } \\
\left(26^{\circ} 14^{\prime} \mathrm{N}\right. \\
\left.78^{\circ} 15^{\prime} \mathrm{E}\right)\end{array}$ & $\begin{array}{l}7-7-1963 \\
6-6-1968\end{array}$ & $\begin{array}{r}5-10-1963 \\
15-12-1968\end{array}$ & $\begin{array}{l}95(105) \\
80(80)\end{array}$ & $\begin{array}{l}0.29 \pm 0.02 \\
0.28 \pm 0.07\end{array}$ & $\begin{array}{l}31 \pm 2 \\
22 \pm 6\end{array}$ \\
\hline $\begin{array}{l}\text { Bombay } \\
\left(18^{\circ} 54^{\prime} \mathrm{N},\right. \\
\left.72^{\circ} 49^{\prime} \mathrm{E}\right)\end{array}$ & $\begin{array}{r}17-6-1963 \\
12-7-1963 \\
9-8-1963 \\
\text { June } 1964 \\
20-7-1966 \\
3-6-1967 \\
27-6-1967 \\
20-7-1967 \\
3-8-1967 \\
25-5-1968 \\
25-5-1970 \\
17-6-1970 \\
16-7-1970\end{array}$ & $\begin{array}{r}6-7-1963 \\
6-8-1963 \\
20-8-1963 \\
\text { July } 1964 \\
12-9-1966 \\
26-6-1967 \\
19-7-1967 \\
2-8-1967 \\
9-10-1967 \\
16-6-1968 \\
16-6-1970 \\
16-7-1970 \\
2-8-1970\end{array}$ & $\begin{array}{l}55(253) \\
50(253) \\
45(253) \\
55(196) \\
65(156) \\
43(237) \\
66(237) \\
66(237) \\
52(237) \\
75(138) \\
54(263) \\
50(263) \\
50(263)\end{array}$ & $\begin{array}{l}0.34 \pm 0.03 \\
0.94 \pm 0.05 \\
0.17 \pm 0.03 \\
0.85 \pm 0.08 \\
0.31 \pm 0.04 \\
0.20 \pm 0.02 \\
0.20 \pm 0.02 \\
0.15 \pm 0.02 \\
0.16 \pm 0.02 \\
0.36 \pm 0.04 \\
0.19 \pm 0.02 \\
0.18 \pm 0.02 \\
0.15 \pm 0.02\end{array}$ & $\begin{array}{r}86 \pm 8 \\
240 \pm 13 \\
43 \pm 8 \\
170 \pm 16 \\
49 \pm 6 \\
47 \pm 5 \\
47 \pm 5 \\
36 \pm 5 \\
39 \pm 5 \\
50 \pm 6 \\
50 \pm 5 \\
47 \pm 5 \\
40 \pm 5\end{array}$ \\
\hline $\begin{array}{l}\text { Khandala } \\
\left(18^{\circ} 47^{\prime} \mathrm{N},\right. \\
\left.73^{\circ} 55^{\prime} \mathrm{E}\right)\end{array}$ & $\begin{array}{r}25-9-1961 \\
21-5-1963 \\
17-7-1963 \\
11-8-1963 \\
19-8-1963 \\
1-6-1967 \\
5-7-1967 \\
31-7-1967 \\
26-8-1967 \\
30-5-1970 \\
26-6-1970 \\
10-7-1970 \\
31-7-1970 \\
17-8-1970 \\
30-8-1970\end{array}$ & $\begin{array}{r}12-12-1961 \\
12-7-1963 \\
7-8-1963 \\
18-8-1963 \\
10-9-1963 \\
4-7-1967 \\
27-7-1967 \\
23-8-1967 \\
1-9-1967 \\
25-6-1970 \\
9-7-1970 \\
30-7-1970 \\
16-8-1970 \\
29-8-1970 \\
26-9-1970\end{array}$ & $\begin{array}{c}70(637) \\
125(508) \\
115(508) \\
80(508) \\
75(508) \\
78(457) \\
51(457) \\
88(457) \\
55(457) \\
100(491) \\
65(491) \\
80(491) \\
75(491) \\
65(491) \\
90(491)\end{array}$ & $\begin{array}{l}0 \cdot 10 \pm 0.01 \\
1 \cdot 15 \pm 0.06 \\
0.48 \pm 0.04 \\
0 \cdot 70 \pm 0.04 \\
0 \cdot 60 \pm 0.03 \\
0.23 \pm 0.02 \\
0 \cdot 29 \pm 0.02 \\
0.23 \pm 0.09 \\
0 \cdot 20 \pm 0.02 \\
1 \cdot 19 \pm 0.02 \\
0.23 \pm 0.02 \\
0.21 \pm 0.02 \\
0.21 \pm 0.02 \\
0.18 \pm 0.02 \\
0.18 \pm 0.02\end{array}$ & $\begin{array}{r}64 \pm 6 \\
580 \pm 31 \\
240 \pm 20 \\
360 \pm 20 \\
305 \pm 16 \\
105 \pm 9 \\
130 \pm 9 \\
105 \pm 40 \\
91 \pm 9 \\
93 \pm 10 \\
113 \pm 10 \\
103 \pm 10 \\
103 \pm 10 \\
88 \pm 10 \\
88 \pm 10\end{array}$ \\
\hline $\begin{array}{l}\text { Kodaikanal } \\
\left(10^{\circ} 14^{\prime} \mathrm{N}\right. \\
\left.77^{\circ} 28^{\prime} \mathrm{E}\right)\end{array}$ & $\begin{array}{l}14-1-1961 \\
25-6-1963 \\
10-6-1968\end{array}$ & $\begin{array}{r}31-12-1961 \\
1-11-1963 \\
22-11-1968\end{array}$ & $\begin{array}{c}140(170) \\
110(195) \\
82(82)\end{array}$ & $\begin{array}{l}0.20 \pm 0.06 \\
0.28 \pm 0.02 \\
0.21 \pm 0.02\end{array}$ & $\begin{array}{l}40 \pm 10 \\
55 \pm 4 \\
17 \pm 2\end{array}$ \\
\hline \multicolumn{6}{|c|}{$\begin{array}{l}\text { Errors indicated are due to counting } 1 \sigma \text { statistics only. } \\
\text { * Annual rainfall is given in parenthesis. } \\
\text { ** To see the variation during different collection periods in a year annual fallout is calculated } \\
\text { based on each sample. }\end{array}$} \\
\hline
\end{tabular}




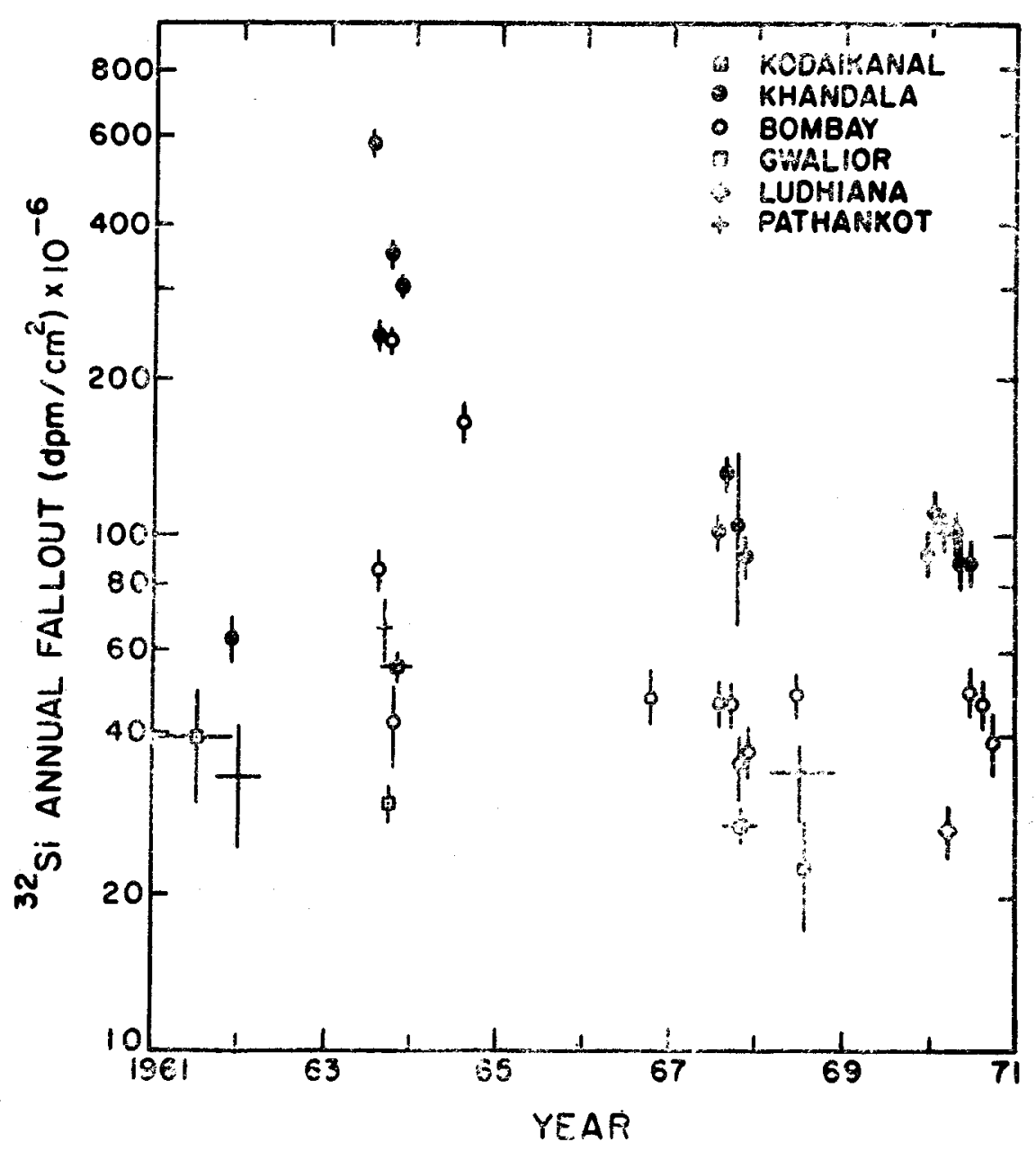

Figure 2. Normalised annual ${ }^{32} \mathrm{Si}$ fallout for each collection period as a function of time during 1961-71 for all stations in India. Except for the collections during 1963 and 1964 when nuclear weapons' contribution is apparent, the ${ }^{32} \mathrm{Si}$ fallout is approximately constant with time at any given station.

values (figure 3). This behaviour is in contrast to the well-established pattern of the specific activity of a radioisotope being independent of the rainfall for stations lying within a narrow latitudinal belt. For example, Krebs and Stewart (1962) showed that for six stations in UK with annual rainfall values differing by as much as a factor of six, the ${ }^{90} \mathrm{Sr}$ concentrations were confined within a very narrow range. A similar result was also obtained for ${ }^{210} \mathrm{~Pb}$ activity in wet precipitations in Japan by Fukuda and Tsunogai (1975).

If the troposphere is considered well mixed as far as the longlived cosmic ray produced isotopes, e.g, ${ }^{32} \mathrm{Si}$ and ${ }^{14} \mathrm{C}$ are concerned, then the ${ }^{32} \mathrm{Si}$ concentrations in rain will be expected to depend on the frequency of vertical mixing of the air masses below and above the cloud level in the troposphere compared to the frequency of rainfall at the same location. If the former is slower, one would expect 


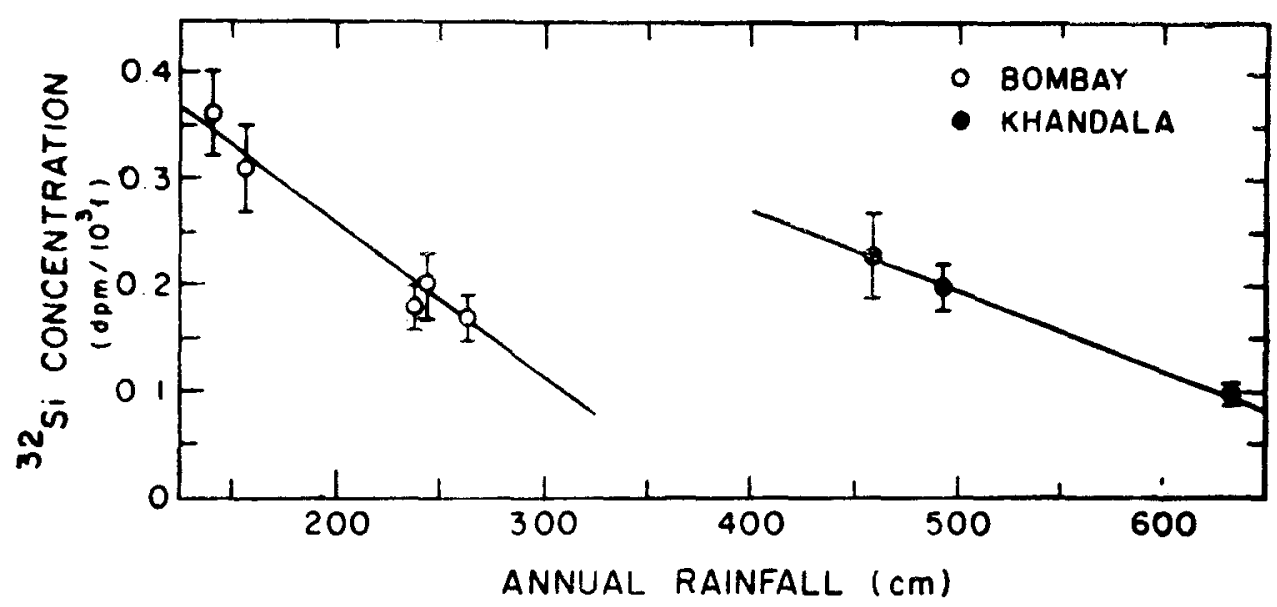

Figure 3. Variation of the annual-mean- ${ }^{32} \mathrm{Si}$ concentration in rain as a function of rainfall at Bombay and Khandala. Notice the inverse correlation. See text for discussion.

an inverse correlation especially at stations like Bombay and Khandala where the rainfall is largely orogenic and is confined to a few months during the entire year.

For other stations, the total annual-fallout is expected to be proportional to rainfall since the mean radioisotope concentrations are found to be independent of rainfall indicating a good vertical mixing during wet precipitations.

\section{Bomb contribution to ${ }^{32} \mathrm{Si}$ production}

As was mentioned earlier, there had been a significant amount of ${ }^{32} \mathrm{Si}$ produced due to nuclear weapons' testing in late 1962. Our annual fallout pattern shown in figure 1 (also figure 2) does show an increase in the ${ }^{32} \mathrm{Si}$ fallout during the years 1963-64. Unfortunately no ${ }^{32} \mathrm{Si}$ measurements were made in 1965 . All the five measurements after 1966 (till 1971) show a uniform value of $5 \mathrm{dpm} / 10^{5} \mathrm{~cm}^{2}$ (table 3) which agrees with the expected fallout rate of this isotope calculated according to the procedure of Lal and Peters (1967); see figure 22 of their article.

In order to evaluate the increase in the ${ }^{32} \mathrm{Si}$ inventory of the natural reservoirs due to nuclear explosions, lake Tansa (situated at about $80 \mathrm{~km}$ from Bombay) was chosen. The lake came into existence more than a hundred years ago and it derives most of its water from the rainfall in the catchment area. The lake is full towards the end of the monsoon season (September) and is drained out to $\sim 25 \%$ of its maximum before the beginning of the next monsoon season (mid June). On an average three quarters of the water gets replenished and one quarter is carried through. We have made several ${ }^{32} \mathrm{Si}$ measurements of the Tansa lake water at irregular intervals during 1963-72, the results of which are shown in table 5. For the sake of comparison the ${ }^{32} \mathrm{Si}$ concentrations in Bombay rains are also shown in table 5. The Tansa lake water had a ${ }^{32} \mathrm{Si}$ concentration of $0.2 \mathrm{dpm} / 10^{3}$ litres in 1963 pre-monsoon period which gradually came down to $0.12 \mathrm{dpm} / 10^{3}$ litres during the pre-monsoon period 1972. Only two sets of data, 1967-68 and 1971-72 
Table 5. Comparison of ${ }^{32} \mathrm{Si}$ concentration in Bombay rainwater and Tansa Lake water during 1963-72.

Period of collection $\frac{{ }^{3} \text { Si concentration }\left(\mathrm{dpm} / 10^{3} \text { litres }\right)}{\begin{array}{c}\text { In Tansa } \\ \text { lake water }\end{array}}$

\author{
5th April 1963 \\ 31st May 1963 \\ 14th June 1963 \\ 17th June to 20th August 1963 \\ June-July 1964 \\ June-October 1967 \\ 15th May 1968 \\ 25th May to 16th June 1968 \\ 30th May to 2nd July 1971 \\ 18th April 1972
}

$\begin{array}{cc}0.21 \pm 0.02 & \ldots \\ 0.21 \pm 0.02 & \cdots \\ 0.20 \pm 0.02 & \cdots \\ \ldots & 0.60 \pm 0.10 \\ \ldots & 0.85 \pm 0.08 \\ \ldots & 0.18 \pm 0.02 \\ 0.14 \pm 0.01 & \ldots \\ \ldots & 0.36 \pm 0.04 \\ \ldots & 0.20 \pm 0.03 \\ 0.12 \pm 0.02 & \cdots\end{array}$

can be used for comparison. The 1967 rainwater has a ${ }^{32} \mathrm{Si}$ concentration of $(0 \cdot 18$ $\pm 0.02) \mathrm{dpm} / 10^{3}$ litres compared to the 1968 pre-monsoon lake water value of $0 \cdot 14 \pm 0.01$. Similarly the 1971 rainwater has a concentration of $(0.20 \pm 0.03)$ $\mathrm{dpm} / 10^{3}$ litres compared to the 1972 pre-monsoon lake water concertration $(0 \cdot 12$ \pm 0.02 ). This comparison leads us to infer that the ${ }^{32} \mathrm{Si}$ concentration of Tansa lake water is approximately half that of the rain water ${ }^{32} \mathrm{Si}$ concentration of the previous year. Using the 1963 pre-monsoon lake water value of $0.2 \mathrm{dpm} / 10^{3}$ litres, we can now calculate the 1962 rain water ${ }^{32} \mathrm{Si}$ concentration to be $0.4 \mathrm{dpm} /$ $10^{3}$ litres which corresponds to a fallout of $8 \times 10^{-5} \mathrm{dpm} / \mathrm{cm}^{2}$. This value smoothly fits in with the rest of the ${ }^{32} \mathrm{Si}$ data (figure 1, table 3). Based on the anrual fallout of ${ }^{32} \mathrm{Si}$ during 1962,1963, 1964 and 1966, we estimate the mean annual fallout during the years 1962-64 to be 2.5 times the mean annual fallout observed during years after 1966. This amounts to a total $2.2 \times 10^{-4} \mathrm{dpm} / \mathrm{cm}^{2}$ which is $\sim 1 \%$ of the inventory of ${ }^{32} \mathrm{Si}$ in the oceans, viz., $2 \times 10^{-2} \mathrm{dpm} / \mathrm{cm}^{2}$ (Somayajulu et al 1973).

\section{Conclusions}

(i) Based on the observed fallout of "Be and ${ }^{35} \mathrm{Si}$ during 1958-59 as well as of ${ }^{22} \mathrm{Na}$ and ${ }^{32} \mathrm{Si}$ during 1963-64, we conclude that significant amounts of these nuclides were produced in nuclear detonations during these or in previous years. This conclusion is supported by observations of fallout of ${ }^{\circ} \mathrm{Sr}$.

(ii) The 'excess' bomb produced activities ${ }^{32} \mathrm{Si}$ and ${ }^{22} \mathrm{Na}$ are removed from the atmosphere with a half-period of less than 1 year.

iii) The bomb produced 'excess ${ }^{32} \mathrm{Si}$ ' amounts to only about $1 \%$ of its inventory in the oceans.

(iv) We observe an inverse correlation between the annual-mean concentration of ${ }^{82} \mathrm{Si}$ and annual rainfall at the two high rainfall stations, Bombay and Khandala. The implications of this observation are discussed in the text. 


\section{Acknowledgements}

It is a pleasure to thank Dr $N$ Bhandari of the Physical Research Laboratory and Dr D P Kharkar, Messrs B S Amin, P K Pawar, P K Talekar and Dr A S Tamhane, our former colleagues at the Tata Institute of Fundamental Research for help during the collection and on-the-site processing of some of the rainwater samples.

\section{References}

Bhandari N 1965 Ph.D. Thesis (Bombay University), p. 154

Bhandari N, Lal D and Rama 1970 J. Geophys. Res, 732974

Bhandari N and Rama 1963a J. Geophys. Res. 681959

Bhandari N and Rama 1963b J. Geophys. Res. 683823

Clausen H B $1973 \mathrm{~J}$. Glaciol. 12411

Dansgaard W, Clausen H B and Aarkrog A 1966 J. Geophys. Res. 715474

Fukuda K and Tsunogai S 1975 Tellus 27514

Goel P S 1956 Nature (London) 1781458

Goel P S, Narasappaya N, Prabhakara C, Thor Rama and Zutshi P K 1959 Tellus 1191

Gopalakrishnan S, Rangarajan C, Joshi L U, Kapoor D K and Eapen C D 1973 Bhabba Atomic Research Centre Report 679 pp. 124

Health and Safety Laboratory 1971 Fallout Program Quarterly Summary Report HASL-245

Jantsch K 1967 Kernenergie 10 Heft 389

Jaworowski Z and Kownacka L 1976 Nature (London) 263303

Joshi L U, Rangarajan C and Gopalakrishnan S 1969 Tellus 21107

Kharkar D P, Lal D and Somayajulu B L K 1963 in Radioactive Dating (Vienna: IAEA) p. 175

Kharkar D P, Nijampurkar V N and Lal D 1966 Geochim. Cosmochim. Acta 30621

Krcbs A and Stewart N G 1962 in Nuclear radiation in geophysics, eds. H Isreal and A Krebs p 241

Lal D, Nijampurkar V N and Somayajulu B L K 1970a Galathea Report (Danish Science Press) 11247

Lal D, Nijampurkar $\mathrm{V} N$ and Rama 1970b in Isotope hydrology (Vienna: IAEA) p 847

Lal D and Peters B 1967 Handbuch der Physik 46551

Lal D and Rama 1966 J. Geophys. Res. 712865

Lal D and Suess H E 1968 Ann. Rev. Nucl. Sci. 18407

Lambert G, Ardouin B, Nezami M and Polian G 1966 Tellus 18421

Nijampurkar V N 1974 Ph.D. Thesis (Bombay University) p. 165

Poet S E, Moore H E and Martell E A 1972 J. Geophys. Res. 776515

Rangarajan C, Gopalakrishnan S, Chandrasekharan V R and Eapen C D 1975 J. Geophys. Res. 80845

Somayajulu B L K, Lal D and Craig H 1973 Earth Planet Sci. Lett. 18181

Somayajulu B L K and Zutshi P K $1961 X$ Cosmic Ray Symp. Madras

Turekian K K, Nozaki Y and Benninger L K 1977 Ann. Rev. Earth Planet. Sci. 5227 